\title{
Social Responsibility of Pharmaceutical Industries: Feasibility of CSR for Corporates
}

\author{
Smita Pandey, Bindu Ronald
}

\begin{abstract}
International Human Rights Law regards certain rights as inherent to all human beings. These rights are granted to them regardless of race, sex, nationality, ethnicity, language, religion, or any other status. The responsibility of granting these rights to its citizens falls as an obligation on government. On the contrary, corporate have evolved on the basic premise of profit devoid of any human rights responsibility. It's not erroneous to say that Human rights and corporate are incongruous nexus since the ages. The corporates are bound by certain moral obligations though. This moral responsibility of corporates towards society which is commonly termed as Corporate Social Responsibility (hereinafter CSR) is nothing new as a concept. The corporates world over have been taking refugee under this and shrugging their responsibility towards the society in the name of CSR as it was at their whims and fancy. In 2008, responding to the invitation by the Human Rights Council for the Special Representative of the Secretary-General on the issue of human rights and transnational corporations and other business enterprises to submit his views and recommendations for its consideration, Prof. John Ruggie, of Harvard University, presented a report as conceptual and policy framework to anchor the business and human rights debate, and to help guide all relevant actors. The framework comprised of three core principles: the State duty to protect against human rights abuses by third parties, including business; the corporate responsibility to respect human rights; and the need for more effective access to remedies (which can be termed as Protect, Respect \& Remedy). Ruggie report and recent changes in the trend has brought worldwide attention to the conditions of those living in less developed countries and their human rights. India also amended its Company Law in 2013 to make CSR mandatory for certain bracket of companies. Recently Pfizer put on hold on the sale and marketing of its products which was used by the state as lethal injections for capital punishment in its country. The reason cited was moral responsibility towards society. The question arises that do the pharmaceutical companies have heightened responsibility towards society? Is $2 \%$ mandatory CSR enough for pharmaceutical companies? Do pharmaceutical companies have a common but differentiated responsibility towards society because of basic reason of its customer are choosing their products by choice but because they need it to fulfill their basic human right of right to life? By answering these questions and analyzing Ruggie report with special reference to pharmaceutical companies, the researchers have looked into the merging responsibility of corporate and government towards human rights. The research is purely a doctrinal study with the help of secondary data. The research article has limited its universe to the Pharmaceutical Companies, as they need to have a heightened sense of moral responsibility because of the nature of their consumers and products. The researchers have also tried to posit a theory of
\end{abstract}

Revised Manuscript Received on March 2, 2020.

Smita Pandey*, Symbiosis Law School, Pune, Symbiosis International (Deemed University), Pune, India. Email: smita.pandey@symlaw.ac.in

Dr. (Prof.) Bindu Ronald, Symbiosis Law School, Pune, Symbiosis International (Deemed University), Pune, India .Email: bronald@symlaw.ac.in
CSR for protection of basic human rights of access to medicines by pharmaceutical companies, which will be ultimately helpful towards policy-making decisions of southbound countries.

Keywords: CSR, Human rights, Pharmaceutical Companies, Pfizer

\section{INTRODUCTION}

Only States have been responsible for ensuring Human Rights, which are essential rights, to be provided to human beings at all cost. This scenario has existed since long, but now the promoters of this right have realized that it is a responsibility to be carried not by the state alone (RUGGIE, J. 2007). The international law concentrates majorly on the states and thus it can be safely said that they are the center of the law as their focal points. The focus has now shifted or somewhat increased its legal obligation compass to also include actors other than states like NGOs, liberation organization, and companies (Paust, J., 2002). This shift is not only subjected by academicians, the United Nations ('UN'). Corporate tend to have a marked effect on the realization of fundamental rights. This power has led to many initiatives, but not mandatory. They just give a broad outline of the responsibilities of companies (Alston, P., 2005)

In 2005, a need was felt by the United Nations Human Rights Council (UNHRC) to appoint a Special Representative to look into the various issues related to human rights vis-à-vis the business organizations. UNHRC then asked the UN Secretary-General to appoint a representative especially for this purpose (which could be termed 'SRSG'). A report known as the "UN Norms on the Responsibilities of Transnational Corporations and distinctive Business Enterprises concerning Human Rights" (hereinafter "the Norms") was proposed and accepted by UNHRC. Later on, an esteemed professor from Harvard University, Prof. John Ruggie, was appointed to frame a report around this issue. After a thorough research on the issue from each angle, the professor presented a critical report highlighting the need of corporate to pay heed towards Human rights. The report was presented in April 2008, was a framework (henceforth 'the Ruggie framework') for the corporate to follow so that human rights ensured.

\section{REVIEW OF LITERATURE}

It's not erroneous to say that Human rights and corporate are incongruous nexus since the ages. Ruggie report and recent changes in the trend has brought worldwide attention to the conditions of those living in less developed countries and their human rights. The review of the literature was done to satisfy the intellectual quest of understanding the nuances of the Ruggie Report and the heightened responsibility of

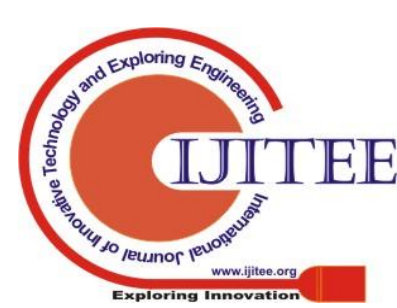




\section{Social Responsibility of Pharmaceutical Industries: Feasibility of CSR for Corporates}

pharmaceutical companies towards protection and regard of human rights.

Angell [2004] has presented the view of public at large. He thinks that Public at large believe that the pharmaceutical industry has been at undue advantage when they are associating with governments, policy makers and regulators, healthcare practiti0ners, and the public in general. It is a one sided view which has been presented by the author. [3]

Brody [2013]. In this enlightening book for the medical professional, the author, Dr. Howard Brody, depicts the complex relationship between the medical professional and the pharmaceutical industry. He looks at how this relationship often betrays the public trust, and he offers strategies to shift the dependence of medicine on industry. He contemplates, how modern medicine breaks the trusted physician-patient relationship by being "hooked" to the pharmaceutical industry, where gifts and rewards influence physicians' decisions and medical institutions are dependent on pharmaceutical support, all in a form likened to addiction. [6]

Santoro [2005] he has discussed all the issues which are moral, ethical, scientific and economical related to research, clinical trial, human rights, marketing, advertising and fair equity in connection to pharmaceutical industry. It has also touched upon the issue of intellectual property rights and access to medicine with a fair estimate of future of pharmaceutical industry. [17]

Koski [2005] In this essay, he argues that the ubiquitous notion of a special moral obligation as an expression of emotionally charged intuitions involving sacred or protected values and an aversive response to betrayal in an asymmetric trust relationship. he then reviews the most common arguments used to justify the claim that the pharmaceutical industry has a special moral obligation and show why these justifications fail. Taken together, these conclusions call into question the conventional ideologies that have traditionally animated the debate on whether the pharmaceutical industry has special duties of beneficence and distributive justice with respect to the impoverished in dire need of their products. Although the paper is argumentative but overlooked the human rights of a human towards a healthy life. [11]

Almashat et al. [2010] This study examined trends from 1991 to 2010 in federal and state criminal and civil actions against pharmaceutical companies in order to address the question of such high dealing of money associated with pharmaceutical industries. The authors took the case study of the data which stated that U.S. spending on prescription drugs had increased from $\$ 40$ billion in 1990 to $\$ 234$ billion in 2008. [1]

PricewaterhouseCoopers [2006] the study presented the downfall of the pharmaceutical industry's stature in the society because of the ill practices of the corporate against the society. One of the views presented says, "[w]e find it quite incredible that we could be equated with an industry [tobacco] that kills people as opposed to cures them'". These

practices have begun to eclipse the positives aspects of this once esteemed industry in the public consciousness. At the same time pharmaceutical industry executives continue to report a failure to comprehend how an industry responsible for saving so many lives could be held in such low public esteem. [14]

Harris [2004] Faced with public policy implications that include increased federal regulation, anti-industry political lobbying, higher regulatory barriers for marketing authorization, exclusion from formulary listings (preferred lists of drugs covered by prescription drug insurance programs), and patient/prescriber product boycotts, status quo inaction and rhetorical argumentation by the prescription drug industry no longer remains an option., former Editor and Chief of the New England Journal of Medicine and outspoken industry critic, concedes, " [d] espite all its excesses, this is an important industry that should be saved - mainly from itself' '[7]

David Bilchitz [2010] In his paper has put forth the analysis of Ruggie Report from the perspective of responsibilities assigned to companies through CSR and suggestions of Ruggie report on the same. The paper has done an exhaustive analysis of the report and has touched upon the importance of corporate having a responsibility to protect rather than respect the fundamental rights of human. The paper forms an excellent platform for understanding the nuances of Ruggie report but has not touched upon the reeling issue of pharmaceutical companies having differential responsibility towards the protection of fundamental rights of human beings. [5]

James M. Huebner [2014] in his paper has explained the ubiquitous notion of an individual having moral obligation because it is an expression of passionately thrilling perceptions consisting of sanctified or secure principles and an adverse reaction to treachery in a disproportionate conviction of a relationship. The paper argues the importance of the conventional ideologies which transcends to age old vigorous debate over the special duties of pharmaceutical industry towards the impoverished citizens who are in dire need of their pharmaceutical products under the concept of beneficence and distributive justice. The paper has not presented the thought on the responsibility of pharmaceutical industries towards fundamental and human rights. [8]

Klaus M. Leisinger [2005] has debated that a company privately is not under any social obligation to provide for basic health care in their own country let alone any other developing country. He contended that even if they are mandated socially they will lack other organizational capabilities to do so. Nevertheless, the paper concludes with the thought that these kinds of organizations have a certain kinds of responsibilities which should be divided under certain classifications which should be named as "what they must do", "what they ought to do", and "what they can do". Still, there is no clear acceptability of the responsibility of pharmaceutical companies as 
a protector of human rights. [10]

D. B. Resnik [2001] This paper discusses the economic, legal, moral, and political difficulties in developing drugs for the developing world. It argues that large, global pharmaceutical companies have social responsibilities to the developing world, and that they may exercise these responsibilities by investing in research and development related to diseases that affect developing nations, offering discounts on drug prices, and initiating drug giveaways.

However, these social responsibilities are not absolute requirements and may be balanced against other obligations and commitments in light of economic, social, legal, political, and other conditions. [15]

The review of literature presented with varied views of authors regarding the moral obligations of pharmaceutical industries but the author could not find paper connecting the corporate social responsibility of these industries in coherence with Ruggie report.

\section{SCOPE AND STATEMENT OF THE PROBLEM}

International Human Rights Law regards certain rights as inherent to all human beings. These rights are granted to them regardless of race, sex, nationality, ethnicity, language, religion, or any other status. The responsibility of granting these rights to its citizens falls as an obligation on government. On the contrary, corporate have evolved on the basic premise of profit devoid of any human rights responsibility. It's not erroneous to say that Human rights and corporate are incongruous nexus since the ages. Ruggie report and recent changes in the trend has brought worldwide attention to the conditions of those living in less developed countries and their human rights. Recently Pfizer put on hold on the sale and marketing of its products which was being used as lethal injections for capital punishment in its country, citing moral responsibility towards society. The overlapping of responsibility of corporate and government towards human rights has led to smudging it to the level that pinpointing it to a party has become difficult. The pharmaceutical industry has a differential responsibility towards human rights of society beyond corporate social responsibility. The developing nations will be able to benefit a lot with this heightened responsibility of pharmaceutical companies.

\section{RESEARCH QUESTIONS}

1. Is the Ruggie Report's claim that "corporations essentially have only a responsibility to respect fundamental rights" is inclusive of "responsibility to protect"?

2. Do the "private enterprises have responsibilities to society that can be categorized as what they must do, what they ought to do, and what they can do"?

3. Does "Pharmaceutical corporations are presented with positive obligations for the realization of fundamental rights"?

\section{OBJECTIVES OF THE STUDY}

- To present the importance of inclusion of 'responsibility to protect' under 'responsibility to respect' the fundamental rights.

- To understand the difference between the must, ought and can do as responsibilities of the corporate.

- To analyze the differentiated responsibility of pharmaceutical companies towards the protection of fundamental rights.

\section{METHODOLOGY, TOOLS, AND TECHNIQUES}

The methodology adopted for the research article is purely doctrinal research with the case study of Pfizer with the help of secondary data. The research article has limited its universe to the Pharmaceutical Companies, as they need to have a heightened sense of moral responsibility because of the nature of their consumers and products and thus Pfizer's decision to put on hold the sale and marketing of its products which the state used as lethal injections for capital punishment in its country, is taken as a case study.

\section{RUGGIE REPORT: THE BACKGROUND}

The UNHRC presented a document known as the "UN Norms on the Responsibilities of Transnational Corporations and Other Business Enterprises concerning Human Rights" in the year 2003. The "Norms" looked for "laying out the human rights and ecological duties inferable from business", Those duties were intended to be obligatory commitments forced upon partnerships by universal law. "the Norms" distinguish these rights as being pertinent to organizations incorporated various obvious competitors, for example, work and ecological rights just as a general catch-all arrangement that companies might be in charge of the full scope of human rights inside their 'range of authority'. All things considered, "the Norms" went past the intentional activities that had until this point been the predominant system where corporate obligation regarding the acknowledgment of human rights had been verbalized. They forced wide-running obligations upon business for the acknowledgment of central rights while likewise sketching out the shapes of a worldwide lawful system that would oversee transnational companies and different business endeavors around there. "the Norms", it was asserted, inferred their lawful specialist "from their sources in settlements and standard global law, as a repetition of legitimate universal standards appropriate to organizations."

When "the Norms" was presented, the two fractions of the stakeholders had an opposing view to it. On one hand the business community represented by International Chamber of Commerce and International Organization of Employers, turned tight lipped and restrained towards their reaction to it. On the other hand, the NGOs advocating the cause of human rights being given prominence by corporate, welcomed it with open hands. Ultimately, the 


\section{Social Responsibility of Pharmaceutical Industries: Feasibility of CSR for Corporates}

Commission declared after a long deliberation, that "the Norms" had 'no real standing' and that the Sub-Commission 'should not play out any checking limit in such a way'. A year on from then, UNHRC proposed UN Secretary-General to appoint a representative especially for this purpose and to look into the issue of conflict between corporate and human rights.

\section{A. The Responsibility of the Corporate to Respect}

The crucial homogenizing of some portion of Ruggie's structure is, from numerous points of view, his case that corporate partnerships have the particular obligation to regard the fundamental rights of a human. The extent of this obligation,

he asserted, is characterized generally by 'social desires' and the thought of an organization's 'social permit to work.' The obligation to regard includes successfully 'making no mischief'. This goes past an aloof duty and can involve making positive strides. Releasing the obligation expects the reference to the thought of due steadiness. "This idea portrays the means an organization must take to wind up mindful of, anticipate, and address unfriendly human rights effects". The extent of the obligation can be featured by three arrangements of variables. In the first place, the settings in which the day to day working of business happen and the specific difficulties in relation to granting of rights of human difficulties that may emerge, are to be considered and analyzed. Furthermore, the effect of trade upon rights of human inside these particular settings should be considered. At long last, the potential for business exercises to add to maltreatment through associations with different specialists, for example, colleagues, providers, state associations, performers which are not state oriented- should be put in thoughts. The organizations which are working for social causes and the rights of human as fundamental rights do certain due diligence on the companies related to it. The parameters for such due diligence are set by referring to International Bill of Rights and conventions of the International Labour Organization as they are considered as paramount in exemplifying the benchmarks for human rights.

It is perceptible that "the Norms" place a lot more extensive scope of commitments upon companies to 'advance, secure the satisfaction of, regard, guarantee regard of, and ensure human rights perceived in universal just as national law' inside their circle of action and impact. Ruggie started his dialogue for idea of corporate commitments by scrutinizing the methodology undertaken by "the Norms". He asserted that "the Norms" endeavor to distinguish a predetermined rundown of those human rights on whom the organizations might are dependent. In connection to them, "the Norms" broaden the whole scope of obligations that States have with the stipulation that organizations have such obligations where they fall inside an enterprise's 'range of prominence' and that such obligations are 'auxiliary' as opposed to 'essential'. Ruggie scrutinized this system for endeavoring to characterize a 'constrained rundown of rights connected to uncertain and far-reaching duties' instead of 'characterizing the particular obligations of organizations as to all rights. So as to catch precisely the contrasts amid Ruggie's stand and that illustrated in "the Norms", it is important to examine specifically the specialized significance of the commitments to regard, ensure and satisfy in universal law in relation to rights of human.

\section{B. Responsibility to Respect as 'Negative' Core}

The major component of the obligation to regard appears as a negative obligation to abstain from encroaching privileges of someone else, 'but essentially, cause no damage'. Ruggie asserted that it is the 'pattern desire for each organization in all circumstances'. However, there might be extra obligations that partnerships have, specifically for their conditions: Ruggie perceived that these might emerge where organizations play out certain open capacities or have embraced extra responsibilities willfully. These duties don't, in any case, will be applied in each and every circumstance. It should be applicable in the situation where they should look into the matter and have not applied it. Additionally, in investigating the sphere of the obligation to regard, The Report has exemplified in so many words if results are not according to the parameters set then they should not be embraced. This is prima facie the answer to the first question.

\section{The Role of the State and Corporation}

While "the Norms" perceived that specific rights might not relate to organizations, they 'present no genuine guideline for separating fundamental duties towards rights dependent on an individual public jobs performed by states and partnership'. While enterprises might be 'support system of society', Report guaranteed they are 'specific financial support system', not 'popularity based open establishments'. The varying idea of companies and states hence implies that corporate "obligations can't and ought not just to mirror the obligations of States". Thus, Ruggie affirmed, by their very nature, partnerships don't have a general job in connection to human rights like states however a particular one". Ruggie, in this way, endeavored in his structure to distinguish the 'particular duties of organizations in connection to human rights'. His case that enterprises have just a duty to regard mirrors this endeavor to catch the specific job they should play in connection to basic rights.

It is clear along these lines that organizations are basically substances made and managed through law so as to achieve various social and individual advantages that stream from their different lawful character. Plainly, must the benefits of business character be joined by severe social damages; at that point, there would be a requirement for lawful confinements to be put on enterprises to prepare for those damages. Such damages may in actuality emerge from the very truth that the focal point of corporate action has frequently been after accomplishing an incentive for its investors without forcing full obligation regarding its activities on the same investors: many of them have contended that "this makes a structure which is obsessive in the quest 
for benefit". The requirement for the guideline to prepare for damages that emerge due to corporations and trade units could give a standardizing premise to the commitments which were spill out of Ruggie's obligation to regard. A person has his rights because of his individuality and it is a duty of corporate to regards and the business arrangement could work as a strategy towards duty regarding such infringement could be maintained a strategic distance from, it is of basic significance to guarantee that partnerships are required at any rate to abstain from hurting such basic rights.

\section{The "Must," "Should" and "Can" Do Corporate Social Responsibility}

The organizations need to pursue certain standards under a corporate social obligation which falls in either the class or must or should or can do.

\section{i. The “Must Do" Aspect of Social Responsibility}

At the point when solicited "What are the duties of huge organizations?" more than $66 \%$ of a worldwide example of 20,000 residents in twenty nations furnished a fascinating however not astonishing aggregate response:

\begin{tabular}{|l|c|}
\hline Expected Duties of Organizations & $\begin{array}{l}\text { Percentage of } \\
\text { response }\end{array}$ \\
\hline Ensure recuperate/wellbeing of laborers & $79 \%$ \\
\hline Treat all representatives similarly & $77 \%$ \\
\hline No gift or defilement & $75 \%$ \\
\hline Ensure nature & $73 \%$ \\
\hline No youngster work & $72 \%$ \\
\hline Make benefits cover regulatory expenses & $68 \%$ \\
\hline Give secure occupations & $64 \%$ \\
\hline
\end{tabular}

Source: "Environics: The Millennium Poll 1999"

Also, 45 percent of those talked with referenced the duty to "react to open perspectives and concerns," 40 percentile anticipated "help to take care of social issues" and 38 percentile needed the organizations to "bolster chanties and network ventures." So, similar data and requirements can be applied everywhere throughout the world.

The non-arguable obligations of the medicine business (are the same in current scenario than before) are to give products and enterprises that adequately satisfy client needs and that can be sold at costs that are aggressive and to the greatest advantage of the company. On the off chance that it is accomplished as a consistence to law just as a concordance with laborers' rights, along insignificant opposite effects and unintentional externalities, an organization's leadership is probably going to be made a decision as dependable If all goes well, such an organization will likewise accomplish benefits that are high in connection to the business normal. In any case, as we are not managing a lose-lose situation in which whatsoever is picked up by one sideways must be mislaid by others; benefits are not sought after to the weakness of the benefit of everyone.

Medicinal companies notwithstanding when simply accepting accountability for which expectations cannot be debatable by and by slowly add to the benefit of all:
- The merchandise along with the enterprises, they produce all sorts of significant the products which is useful for people. Advanced medicines and treatments, for instance, help to lessen passing rates and to avert or fix illnesses. Being an effective pharmaceutical organization in this way implies not exclusively being productive yet, in addition, raising the personal satisfaction of wiped out individuals, staying away from exorbitant hospitalization, and enabling individuals to return to ordinary working lives as opposed to being disabled. The monetary achievement of the organization emerges here because of market accomplishments in the examination, assembling, and dispersion of medications of high social advantage.

- Profits guarantee the protection of profitable occupations, the installment of reasonable compensations and social advantages, commitments toward annuity and protection frameworks, and the advancement of new (and, for feasible worldwide improvement for a total developing populace, truly necessary) specialized arrangements. Additionally, the assets of the company are improved through profits. The corporate gaining assets are possible mostly because of lenient and easy political system and social conditions of a state. The corporate then tend to commit towards the improvement of conditions of state and society. These commitments act as an incentive to the society. Thus, they become beneficial for both.

Although not buying in to a restricted understanding of Milton Friedman's celebrated opinion that the matter of corporate will be business just, where an organization has none additional commitments rather to comply with the law and "the standards of the game", His worry was that binding human and societal qualities into choices of the monetary matters will at last lead to a move from trade components to administrative systems. On occasion when the decision of a reasonable social hierarchy of work is by all accounts so obscured, a reminder about realism which is talking about the limits of corporate commitments is a political need; it makes straightforwardness about which should be normal from the business perspective on a manageable premise. Be that as it may, at that point the comprehension of the job of the state has altered in the course of recent decades, and present-day social orders today relegate to entertainers in the financial subsystem a moderately wide-extending arrangement of commitments.

\section{ii. The "Should Do" Aspect of Social Responsibility}

A great many people in current social orders expect organizations were contending with respectability to evade faulty activity with a reaction to the 'soul' which has a mark of "negligible standard" especially of law as opposed to barely translating the letter of the law. For instance, they anticipate that organizations should pay "living wages" rather than "negligible wages," and to secure nature even in nations where this isn't lawfully required. Essentially, associations today qualify as extraordinary corporate locals if they seek after rules, for instance, rules presented at the United Nations Global Compact.

How did this UN Global Compact show up? UN Secretary-General Kofi Annan 


\section{Social Responsibility of Pharmaceutical Industries: Feasibility of CSR for Corporates}

prophesied that "cross-section comprehensive characteristics into the surface of overall markets and corporate practices would help advance wide social destinations while checking open markets, incited world business pioneers to make globalization work for all the world's kinfolk. To this end, associations are drawn closer to act in their very own corporate spaces on ten norms drawn from the Universal Declaration of Human Rights, the International Labor Organization's Fundamental Principles on Rights at Work, and the Rio Principles on Environment and Development, which structure the UN Global Compact".

Multinational organizations are the central character of globalization. Furthermore its essential recipients, they are progressively expected to satisfy commitments that go past what is required by national laws-particularly in conjecture with failure of the open area to secure the open welfare of certain countries and positively past the fulfillment of momentary investor premiums. The "should do" measurement of social obligation is to examine the corporate situation deliberately, to search for probable susceptibilities and write them in the soul of good CSR, and to ensure that administration and consistence procedures are set up to forestall execution shortfalls.

Obviously, additionally concerning the UN Global Compact, various partners have various meanings of equivocal terms, (for example, "range of authority" or "preparatory guideline") consequently the organization must be certain that others know about what the corporate comprehension of these terms is. This is particularly significant with regards to the human rights standards: Many of the Human rights partners assume that huge organizations have the ability to impact results even in the political field, and along these lines request from enterprises that they utilize their dealing power "to amend hostile conditions even in nations in which a firm has assumed no causal job in their creation," presented by the United Nations put it. The nations, while remembering the uneasiness of past discourses about political obstruction of worldwide partnerships, such requests must be taken care of with extraordinary consideration.

The "UN Global Compact Principles":

Fundamental Rights of a Human

"The Secretary-General asked the world business network to":

"Principle 1: Support and regard the security of global human rights inside their range of authority"

"Principle 2: Make sure their very own partnerships are not complying with in human rights manhandles"

Standards of Work

"The Secretary-General asked the world business network to maintain":

"Principle 3: Freedom of affiliation and the successful acknowledgment of the privilege to aggregate dealing";

"Principle 4: The disposal of all types of constrained and necessary work"

"Principle 5: The successful cancelation of youngster work"

"Principle 6: the disposal of separation in regard to work and occupation"

Condition

"The Secretary-General asked the world business network to":

"Principle 7: Support a prudent way to deal with ecological difficulties"

"Principle 8: Undertake activities to advance more prominent natural duty"

"Principle 9: Encourage the advancement and dispersion of ecologically cordial advances"

Against Corrupt Practices
Principle 10: Businesses should neutralize all types of debasement, including coercion and gift

For research-based medicinal associations, various different estimations become huge, two of which are basic: accessibility to help with endowments in occurrences of extreme urgency along with organization flexibility? Evaluating of the urgency especially of lower middle class family as per each case premise was required.

Parameters required for estimating and measuring the misuse of altruism at the selling point need extra efforts. Authority over exchange is required to stay away from supposed or spillage of the low-estimated medications to the business sectors of mechanical nations. It likewise requires a suitable political condition, including availability with respect to customers in extravagant markets to acknowledge supported value contrasts. Besides, it might require understandings from modern nations not to utilize differential costs proposed distinctly for developing and least developing nations as standards at their own cost guideline frameworks or strategies.

\section{iii. The “Can Do” Aspect of Society's Responsibility}

"Attractive" activities spread an element of social duty that is neither legally necessary nor a practice followed in a standards industry norm. Conveyance on the "can-do" standards of social duty won't secure an organization whose real tasks don't conform to the law or different parts of the "must-do" measurement. However, it can offer individuals considerable social or different favorable circumstances. Wanted activities are, for instance, social advantages through backups arranged in poor nations, for example, free or intensely sponsored dinners for laborers and representatives, nursery schools for single guardians, free preparing chances utilizing organization foundation, or grant programs for the offspring of workers in low-pay gatherings. The additional items may likewise appear as giving free or vigorously sponsored offices for determination of phyco-analysis with social implementation and treatment for representatives with HIV/AIDS or other neediness related sicknesses, for example, TB or jungle fever. Corporate generosity, characterized as use past an organization's genuine business exercises with no particular relationship with direct corporate points of interest and with no monetarily quantifiable rewards consequently, is respected by certain partners with wariness, in light of the fact that these are deliberate benefits and likewise be decreased for instance, at the time when the atmosphere in the corporate condition ends up stricter.

Given across the board neediness and the human enduring related with it, regardless of whether an organization does simply act absolutely as a money related patron for helpful purposes, this ought to be recognized as praiseworthy. As a major aspect of such ventures, an organization may give drugs for eg., Novartis has, for instance, marking an update of comprehension with WHO for giving free of cost treatment to all sick patients on the planet earth until the malady is wiped out from each nation or may put resources into social advancement projects to upgrade the absorptive and 
institutional limit of the beneficiaries. Experience demonstrates that it is generally simple to make a gift to a legislature or a universal association. However, the negligible accessibility of medication at the focal therapeutic shops in a developing or least developed nation's finances does not really imply that it will be accessible and available to rustic or urban networks out of luck. It tends to be incredibly hard to ensure the given drug is available to the desperate patients in the rustic zones of a least created nation at the opportune time, in the correct measurements, and with the patient's consistency.

Organizations that become occupied with such a thorough way make the chance to obtain a social skill in regards to issues of neediness and become acquainted with destitution related substances encounters that don't generally frame some portion of the ordinary universe of an organization.

Commitments from the examination endeavors of the pharmaceutical business additionally fall into the classification of "can-do" standards of social duty. This may pursue the methodology of the "Novartis Institute for Tropical Diseases" submitted at Singapore, whereas a team with others as a joint open private activity free research is led into the sicknesses of neediness, for example, Tuberculosis and fever due to dengue.

The second research question is thus answered.

\section{PHARMACEUTICAL ORGANIZATIONS' SURE COMMITMENTS FOR ESSENTIAL RIGHTS: CONTEXTUAL CONTOURS OF PFIZER}

The drugs produced by Pfizer are always aimed at removing the illness. Reliable with these qualities, Pfizer firmly protested the utilization of its items as deadly infusions for the death penalty. Pfizer's commitment was to guarantee the accessibility of their items to patients who depend on them for therapeutically essential purposes. Simultaneously, they were upholding dispersion confinement for explicit items that have been a piece of, or considered by certain states for their deadly infusion conventions.

These items included "pancuronium bromide, potassium chloride, propofol, midazolam, hydromorphone, rocuronium bromide, and vecuronium bromide". Pfizer's dissemination limitation constrained the clearance of these seven items to a select gathering of wholesalers, merchants, and direct buyers under the condition that they would not exchange these items to remedial foundations for use in deadly infusions. Government buying elements needed to guarantee that items they bought or generally procured were utilized uniquely for medicinally endorsed patient consideration and not for any reformatory purposes.

Pfizer further necessitated that these Government buyers guaranteed that the item is for "possess use" and won't exchange or generally give the limited items to some other gathering. Pfizer reliably checked the conveyance of these seven items, followed up on discoveries that uncovered rebelliousness, and altered arrangements when important to stay predictable with their expressed position against the ill-advised utilization of their items in deadly infusions.
Significantly, this dissemination framework was likewise intended to guarantee that these basic prescriptions were to remain promptly accessible to those patients who depended on them consistently.

\section{About These Products:}

"Propofol, pancuronium bromide, midazolam, hydromorphone, rocuronium bromide, vecuronium bromide, and potassium chloride" are Food \& Drugs Authority have approved, medicinally essential medications directed by authorized therapeutic experts, a large number of times each day, in endeavors to treat disease or spare the lives of patients around the globe. They are settled inside the therapeutic network and keep on serving significant needs in surgeries and different medicines. Pfizer offered these items since they spare or improve lives, and showcased them exclusively for use as demonstrated in the item naming.

Eyewitnesses of the death penalty said the move had all the earmarks of being sizable. However, they said that because of the mystery that administers how states acquire deadly infusion drugs, it was difficult to tell the amount of an effect this change would have on states looking to complete executions sooner rather than later. This is one feature of pharmaceutical organizations having moral commitments towards society and its human rights. The other disputable organ is the entrance to reasonable prescriptions.

\section{PHARMACEUTICAL COMPANIES AND ACCESS TO MEDICINES}

Among every one of the on-screen characters with honest goals in the public arena, regulating agreement is seen that each individual person who bites the dust under states of individual and aggregate neediness since the person in question has no entrance to satisfactory medicinal consideration is a prosecution against the individuals who could avert it yet who for whatever reasons neglect to do as such. The Gaussian bend diagramming the appropriation of ethics and social skill seems to be similar for the two directors and other expert gatherings. In perspective on the intricacy and measurement of the medical issues looked by the three billion individuals whose pay adds up to under $\$ 2$ every day, it is a cliché to express that destitution, and sick wellbeing has numerous sources, and henceforth that manageable arrangements require a multi-pronged methodology. Thus, various entertainers who fortify each other's endeavors need to make a bundle of correlative methods and strategies.

Powerful and effective arrangements need an edified ability to collaborate and to go to a comprehension between each one of the individuals who have something to contribute. Without express and rational endeavors to develop wellbeing framework, train medicinal services laborers, share data with specialists from the open part, instruct patients, and improve wellbeing administrations when all is said in done, quite a bit of what state, organizations working not for profit, or the private segment bring to the table will be consumed by the individuals who have early and better data, better access, and increasingly political power. Under such conditions, the (moderately) 


\section{Social Responsibility of Pharmaceutical Industries: Feasibility of CSR for Corporates}

non-poor are probably going to profit excessively, and the individuals who live in outright neediness will remain underserved.

While the individual entertainers, governments, givers, NGOs, and the private segments might be viable and productive in accomplishing their own particular objectives, no single visible character can settle each issue of normal concern. Various on-screen characters in common society have various ideas, abilities, methods, encounters, and assets. They are likewise determined by various thought processes. Despite the fact that there is a levelheaded and characteristic division of work and duty, collaborations through participation and unconventional unions are attainable. Because of various foundations and encounters, various on-screen characters are probably going to dissect the issues and assess both the issues and the open doors in an unexpected way. Altered or inside and out, various arrangements become likely under such conditions. Joint effort and coordination among the various on-screen characters can prompt cooperative energies and a component of arrangements not accessible from a single entertainer.

CSR along these lines not just includes contending with honesty and a high level of affectability as to partner concerns but on the other hand is communicated by the readiness to coordinate with different section of common society which is working in accordance with some basic honesty. Before participation on explicit ventures can start, notwithstanding, an accord should become to among the individuals who need to collaborate on the meaning of the fundamental issues and thusly on the suitability of the methods and systems being utilized to fathom them. One guide to clarify this method of reasoning could be the "entrance to medications" shortages in the country parts of India.

On the off chance that a partner considers the presence of the pharmaceutical business' protected innovation rights are the fundamental can be said to be select imperative on the entrance of poor rustic patients to drugs, it will be most hard to locate a shared factor for maintainable arrangements of this issue. It has nothing to do with a belief system to perceive that most irresistible illnesses - which record for $45 \%$ of the reasons for death and $63 \%$ of the total death in least developing nations - can be controlled with accessible and moderate meds and devices, which are all off-patent however are not accessible where and when they are required

- Tuberculosis medications are almost $100 \%$ powerful in restoring Tuberculosis. The entire course of six months' costs only $\$ 10$.

- Oral rehydration treatment is exceptionally compelling in treating drying out brought about by diarrheal infections, for $33 \not$ each dosage.

- Pneumonia can be contained up to $90 \%$ with antibiotics for cost of $27 \not$ per portion.

- Malarial can be easily warded off with a $12 \phi$ medicine.

- Measles can be treated to the tune of $85 \%$ viable in averting measles, for as meager as $26 \phi$ per portion.

A meeting was held at Washington to ponder upon protected innovation and the financial matters of universal general wellbeing in 2013, October. They recommended that the diseases which are generally acquired by the impoverished citizens required some basic medicines. These medicines, up to the tune of $95 \%$, are either have terminated license or are now not even licensed. This basically answers the third research question.

\section{CONCLUSION}

Issues and scope for improvement in a society have always been and will always be for crores of individuals presently caught in destitution. Now that CSR is mandatory and the corporate have to put on record they must comply with this duty and subsequently should rise above the "must-do" measurement to apply yearning "great corporate citizenship". Anything less would not exclusively be lamentable, however, would likewise, within the near future, bring about an open impression of being apathetic regarding the greatest social issue within recent memory. Eventually, "society" is nothing else except for the totality of genuine or potential "clients" and their decisions about an organization being "socially capable" decides their selection of items. However, it is "shoppers" on the item and administrations showcases as well as on the "notoriety markets" who tally organizations that are seen to be a piece of the issue and not some portion of the arrangement will in the end face issues with their societal acknowledgment just as an increasingly troublesome political condition and progressively stringent guideline. This again would be counterproductive for the direly required achievements in pharmaceutical research. As the most noticeably awful exhibition of the weakest individual from the business is impacting the picture of the entire business, progressively "social promoting" of corporate social duty inside the pharmaceutical part would profit all companies.

An illuminated method for taking a gander at CSR obligation from a business organization perspective is to consider to be sustainability enthusiastic to fulfill society's desires however much as could reasonably be expected and therefore to develop open altruism. An administrator's announcement in such manner will transmit correct sign with the help of an association and towards the more extensive social order. It's implied that if an organization needs its social duty certifications to be generally known and acknowledged, it should provide details regarding these accomplishments in persuading and effectively available way and to give solid models, best case scenario in its yearly report.

Supported corporate achievement depends, notwithstanding all different elements that fruitful supervisors are so very much aware of, on the fearlessness and creative mind to react to the requirements and welfare of honest partners. It is the need of the hour to hold the agents of globalization accountable for violation of human rights occurring due to aggressive profit making. A believable promise is that there should be informed CSR and it might be able to fence one of the most significant territories of future corporate authority and achievement.

\section{REFERENCES}

1. "Almashat, S., Preston, C., Waterman, T., \& Wolfe, S. 
(2010). Rapidly increasing criminal and civil monetary penalties against the pharmaceutical industry: 1991 to 2010". http://www.citizen.org/documents/rapidlyincreasingcriminalandcivilpen alties.pdf

2. "Alston, P. (2005). Has presented the issue in The 'Not-a-Cat' Syndrome: Can the International Human Rights Regime Accommodate Non-State Actors? Published by Oxford: Oxford University Press, p.3-36."

3. "Angell, M. (2008). Industry-sponsored clinical research: A broken system. Journal of the American Medical Association, 300(9), 1069-1071."

4. "Backer, L.C. (2006). Worldwide Corporations and Transnational Law: The United Nations' Norms on the Responsibilities of Transnational Corporations as a Harbinger of Corporate Social Responsibility in International Law which was published by Columbia Human Rights Law Review, v. 37, p. 287-389."

5. "Bilchitz, D. (2010). The Ruggie Framework: An Adequate Rubric for Corporate Human Rights Obligations. Sur International Journal on Human Rights, 12, 199-232."

6. "Brody, H. (2007). Hooked: Ethics, the medical profession, and the pharmaceutical industry. Lanham: Roman \& Littlefield"

7. "Harris, G. (2004). Drug companies seek to mend their image. The New York

Times."

http://www.nytimes.com/2004/07/08/business/drug-makers-seek-to-men d-their-fractured-image $\cdot h t m l$ ?pagewanted=all\&src $=$ pm

8. "Huebner James M. (July 2014), Moral Psychology and the Intuition that Pharmaceutical Companies Have an 'Extraordinary' Obligation to Society, Journal of Business Ethics, Springer 122 (3), 501-510"

9. "Human Rights Watch, for example, has discharged a report that diagrams the effect that companies can have on an entire scope of fundamental rights. The report focuses on the requirement for universal intergovernmental principles on business and human rights, to manage the maltreatment."

10. "Klaus M. Leisinger (Oct., 2005), The Corporate Social Responsibility of the Pharmaceutical Industry: Idealism without Illusion and Realism without Resignation, Business Ethics Quarterly, Vol. 15, No. 4, pp. 577-594 Published by: Cambridge University Press Stable 27-07-2019 10:19"

11. "Koski, E. G. (2005). Renegotiating the grand bargain. In M. A. Santoro \& T. M. Gorrie (Eds.), Ethics and the pharmaceutical industry (pp. 393-403). New York: Cambridge University Press."

12. "Nolan, J (2005) in his article With Power Comes Responsibility: Human Rights and Corporate Accountability. College of New South Wales Law Journal, v. 28, p. 581-613."

13. "Paust, J., (2002) discussed Human Rights Responsibilities of Private Corporations which was published in Vanderbilt Journal of Transnational Law, v. 35, p. 801-825."

14. "PricewaterhouseCoopers.(2006). Recapturing the vision-Restoring trust in the pharmaceutical industry by translating expectations into actions."

http://www.pwc.com/gx/en/forms/download-anelectronic-version-of-reca pturing-the-vision-restoring-trust-inthe-pharmaceutical-industry-by-trans lating-expectations-intoactions.jhtml

15. "Resnik, D. B. (2001). Developing drugs for the developing world: An economic, legal, moral, and political dilemma. Developing World Bioethics, 1(1)"

16. "RUGGIE, J. (2007). Was published on specific issue of Business and Human Rights: The Evolving International Agenda. presented in American Journal of International Law, v. 101, p.819-840."

17. "Santoro, M. A. (2005). Introduction: Creating a sustainable path for the twenty-first century pharmaceutical industry. In M. A. Santoro \& T. M Gorrie (Eds.), Ethics and the pharmaceutical industry (pp. 1-5). New York: Cambridge University Press"

18. "The voluntary activities incorporate The Organization for Economic Co-operation and Development (OECD) Guidelines for Multinational Enterprises; the International Labor Organization (ILO) which is a Tripartite Declaration of Principles Concerning Multinational Enterprises and Social Policy; and the United Nations (UN), The United Nation Global Compact. The focal point of this article will be on the endeavors to affirm, additionally restricting commitments upon partnerships."

19. "UNITED NATIONS. (2000.) The panel which discussed the issue on Economic Social and Cultural Rights. The Right to the Highest Attainable Standard of Health (General Comment no 14), UN Doc. E/C.12/2000/4 (11 August 2000). Accessible at: <http://www.unhchr.ch/tbs/doc.nsf/(image)/E.C.12.2000.4.En>.31 Mar. 2019."

20. "Weissbrodt, D.; Kruger, M. (2003). Standards on the Responsibilities of Transnational Corporations and Other Business Enterprises concerning Human Rights, which was published in the American Journal of International Law, v. 97, p. 901-922.”

\section{AUTHORS PROFILE}

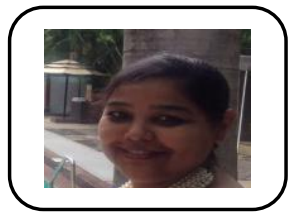

Smita Pandey, is Assistant Professor at Symbiosis Law School, Pune. She is currently pursuing $\mathrm{PhD}$ in Law from $\mathrm{SI}(\mathrm{DU})$. She is also registered Trademark \& Patent Agent. She is triple Masters and double graduate with Science and Textile Chemistry as well as Law. She has various National \& International publications and also conference presentations in the areas ranging from Environment, Women Empowerment, IPR and Corporate Law. She was also granted JRF for her PhD at $\mathrm{SI}(\mathrm{DU})$.

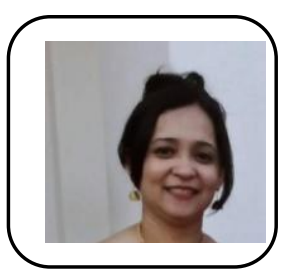

Dr. (Prof.) Bindu Ronald, is Professor and Deputy Director at Symbiosis Law School, Pune. She has handled various projects assigned by government and non-governmental organizations. She also has published and presented various papers at national and international conferences and journals. Her area of specialization is corporate law and competition law along with International law. 